Refitria Febrian Ramdhiana, Asmanur Jannah, Dyah Budibruri

Wibaningwati

Fakultas Pertanian, Universitas Nusa Bangsa Jl. K.H. Sholeh Iskandar KM. 4 Kelurahan Cibadak, Kecamatan Tanah Sereal, Kota Bogor, 16166, Indonesia.

e-mail: refitriaramdhiana@gmail.com e-mail korespondensi: asmanurdjannah@yahoo.com e-mail: dyah_buds@yahoo.co.id

\section{PENGARUH PERLAKUAN PERENDAMAN TERHADAP KARAKTERISTIK TEPUNG TALAS BOGOR (Colocasia esculenta L. Schott) PADA KLON YANG BERBEDA}

\author{
(Effect of Immersion Treatment on the Characteristics \\ of Bogor Taro Flour (Colocasia esculenta L. Schott) in \\ Different Clones)
}

ISSN: 2721-8589 (media online) ISSN: 2721-8597 (media cetak)

\author{
AGRISINTECH \\ Journal of Agribusiness and \\ Agrotechnology

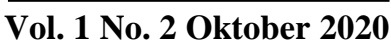

\begin{abstract}
Bogor Talas (Colocasia esculenta L. Schott) is one of the icons of the City of Bogor. What is less favored from Bogor taro is the presence of calcium oxalate crystals that cause itching of the skin, oral mucosa, and esophagus. One way to get rid of itching on taro is to soak taro for one night in water, however, the most effective immersion method and its effect on the characteristics of taro flour is unknown. This research uses a factorial completely randomized design $(R A L-F)$ with two factors, namely clone and immersion factors. Bogor taro clones used clones B-1511 and B-1023, harvested at the age of 9 months, peeled, chopped and given immersion treatment. Immersion tested: control or without immersion (K), immersion in water A), and in 5\% salt solution $G$ ). After soaking, it is drained and dried with a drying oven at a temperature of 55 $o$ C. The dried chips are processed into flour to be then evaluated for their characteristics. Variables observed were yield, water content, kamba density, amylose, amylopectin, starch content, and calcium oxalate content. The results showed that there were significant interactions between clones and immersion treatment on amylose content, amylopectin content and starch content. Soaking treatment in 5\% salt solution for 30 minutes can reduce calcium oxalate levels in taro flour both B-1511 and B 1023 clones. The average yield of flour in B-1511 clones is $26.53 \%$ while for B-1023 clones $26.40 \%$.
\end{abstract}

Keywords: Effect of immersion treatment, clones, taro, flour characteristic

\begin{abstract}
ABSTRAK
Talas Bogor (Colocasia esculenta L. Schott) merupakan salah satu ikon Kota Bogor. Hal yang kurang disukai dari talas bogor adalah adanya kristal kalsium oksalat yang menyebabkan rasa gatal pada kulit, mukosa mulut, dan kerongkongan. Salah satu cara untuk menghilangkan rasa gatal pada talas adalah dengan merendam talas selama satu malam di dalam air, namun, metode perendaman yang paling efektif dan pengaruhnya terhadap karakteristik tepung talas belum diketahui. Penelitian ini menggunakan rancangan acak lengkap faktorial (RAL-F) dengan dua faktor, yaitu faktor klon dan perendaman. Klon talas bogor yang digunakan klon B-1511 dan B-1023, dipanen pada umur 9 bulan, dikupas, dirajang dan diberi perlakuan perendaman. Perendaman yang dicobakan: kontrol atau tanpa perendaman (K), perendaman dalam air A), dan dalam 5\% larutan garam G). Setelah direndam, ditiriskan dan dikeringkan dengan drying oven pada suhu $55^{\circ} \mathrm{C}$. Chip yang sudah kering diolah menjadi tepung untuk kemudian dinilai karakteristiknya. Variabel yang diamati adalah rendemen, kadar air, densitas kamba, amilosa, amilopektin, kadar pati, dan kadar kalsium oksalat. Hasil penelitian menunjukkan bahwa terdapat interaksi yang nyata antara klon dan perlakuan perendaman terhadap kadar amilosa, kadar amilopektin dan kadar pati. Perlakuan perendaman dalam larutan garam 5\% selama 30 menit dapat menurunkan kadar kalsium oksalat pada tepung talas baik klon B-1511 maupun B-1023. Rata-rata rendemen tepung pada klon B-1511 26,53\% sedangkan untuk klon B-1023 26,40\%.
\end{abstract}

Kata kunci: Perendaman, klon, talas, karakter tepung 


\section{PENDAHULUAN}

Tanaman umbi-umbian merupakan salah satu komoditas pertanian yang banyak dijumpai di Indonesia. Umbi diklasifikasikan menjadi golongan mayor dan minor. Golongan umbi mayor adalah ubi kayu dan ubi jalar, sedangkan golongan minor adalah talas, gembili, dan uwi. Golongan umbi mayor banyak digunakan untuk kebutuhan industri seperti produksi tapioka, sedangkan golongan umbi minor belum banyak digunakan dalam skala industri.

Talas merupakan salah satu golongan umbi minor dengan kadar pati tinggi yang dapat dimanfaatkan menjadi keripik maupun gula cair. Talas memiliki jenis dan warna daging yang beragam, namun umumnya adalah berwarna ungu. Talas dengan warna daging kuning dapat dijumpai di Kota Malang, dan cenderung memiliki tekstur yang lebih pulen.

Talas berpotensi untuk diolah menjadi tepung karena kandungan pati sekitar 70$80 \%$ dan tergolong tinggi. Rendemen dari talas juga tinggi, mencapai 28,7\% (Syarif dan Estiasih, 2013) dalam (Farhandi Saputra dkk). Oleh karena potensi tersebut, talas dapat diolah menjadi bahan baku tepung-tepungan. Namun, potensi ini belum banyak dieksplorasi. Selain tepung, olahan ekstrak daun talas juga dapat dimanfaatkan mempunyai kemampuan yang lebih kuat dalam membunuh 50\% larvasida nyamuk (Widhyastini dan Hutagaol, 2014).

Talas merupakan salah satu ikon kota Bogor. Kabupaten Bogor merupakan salah satu daerah penghasil talas tertinggi di Indonesia. Talas dapat tumbuh subur di Bogor karena kesesuaian syarat tumbuh pada wilayah ini. Berdasarkan data Kafah (2012) Ciawi, Megamendung, Cijeruk, Dramaga, dan Caringin termasuk dalam 5 dari 33 kecamatan pada Kabupaten Bogor yang merupakan produsen talas secara kontinu. Produktivitas talas di Kota Bogor ditampilkan pada Tabel 1. Walaupun cenderung fluktuatif, namun rata-rata produktivitas Talas adalah sebesar 7,4 ton/ha pada tahun 2013.

Tabel 1. Produktivitas Talas di Bogor

\begin{tabular}{cccc}
\hline Tahun & Luas Tanam (ha) & Produksi (ton) & Produktivitas (ton/ha) \\
2008 & 157,05 & 894,86 & 5,70 \\
2009 & 160,00 & 914,26 & 5,71 \\
2010 & 177,00 & 986,00 & 5,57 \\
2011 & 94,04 & 895,18 & 9,52 \\
2012 & 103,02 & 876,06 & 8,50 \\
2013 & 118,02 & 1106,07 & 9,37 \\
Rata-Rata & 134,86 & 945,41 & 7,40 \\
\hline
\end{tabular}

Sumber: Dinperta Kota Bogor 2014, dalam Assafa, 2014

Talas Bogor (Colocasia esculenta L. Schott) memiliki banyak variasi mulai dari bentuk daun, warna pelepah, dan rasa. Terdapat beberapa subjenis dari talas bogor, yaitu talas sutera, talas bentul, dan talas ketan. Talas sutera meiliki ciri khas berupa bulu halus seperti sutera dan dipanen pada umur 5-6 bulan. Talas bentul lebih besar dibandingkan talas sutra dan memiliki warna batang yang lebih ungu. 
Talas bentul umumnya dipanen pada umur 8-10 bulan dengan umbi yang berwarna kekuning-kuningan. Talas ketan memiliki warna pelepah hijau tua dan kemerahan. Selain bervariasi dari segi warna dan ukuran umbi, talas bogor juga memiliki variasi dari kandungan kristal. (Syarif dan Estiasih, 2013) dalam (Farhandi Saputra, dkk). Selain jenis talas yang telah banyak di pasaran, Universitas Nusa Bangsa (UNB), memiliki koleksi beberapa klon harapan talas Bogor unggulan, di antaranya talas klon B-1511 dan klon B1023 (Jannah, et al 2019).

Sekalipun memiliki produktivitas yang cukup tinggi, talas bogor tidak banyak dimanfaatkan dalam skala produksi industri karena adanya kristal yang menyebabkan gatal. Rasa gatal yang ditimbulkan oleh umbi dan daun segar ketika pengolahan talas berasal dari kandungan kristal kalsium oksalat yang bersifat toksik. Hal ini menyebabkan rasa gatal pada kulit, mukosa mulut, dan kerongkongan. Salah satu cara untuk menghilangkan rasa gatal yang ditimbulkan talas adalah dengan merendam talas selama satu malam di dalam air, namun, metode perendaman yang paling efektif belum diketahui. Berdasarkan uraian di atas, perlu diteliti tentang perlakuan perendaman pembuatan tepung talas Bogor.

\section{BAHAN DAN METODE}

Penelitian tentang talas ini dilaksanakan di Laboratorium Pengolahan Balai Besar Penelitian dan Pengembangan Pascapanen Pertanian dan di Laboratorium Kimia Universitas Nusa Bangsa Bogor, pada bulan Maret-Juli 2019.

\section{Bahan dan Alat}

Bahan yang digunakan adalah talas bogor klon B-1511 dan B-1023, garam dan air. Alat yang digunakan adalah pisau, wadah plastik, timbangan analitik, ayakan 100 mesh, drying oven dan slicer.

\section{Metode Percobaan}

Rancangan yang digunakan dalam penelitian ini adalah rancangan acak lengkap faktorial (RAL-F) dengan dua faktor, faktor pertama adalah klon dan faktor kedua adalah perendaman sehingga terdapat enam perlakuan kombinasi sebagai berikut.

1. B1511-K: Klon B-1511, tanpa perendaman (kontrol).

2. B1511-A: Klon B-1511, direndam dalam air selama 30 menit.

3. B1511-G: Klon B-1511, direndam dalam larutan garam 5\% selama 30 menit.

4. B1023-K: Klon B-1023, tanpa perendaman (kontrol).

5. B1023-A: Klon B-1023, direndam dalam air selama 30 menit.

6. B1023-G: Klon B-1023, direndam dalam larutan garam 5\% selama 30 menit.

Setiap perlakuan diulang tiga kali, sehingga diperoleh delapan belas satuan percobaan. Model linier dari percobaan ini adalah:

$Y i j k=\mu+\alpha i+\beta j+(\alpha \beta) i j+\varepsilon i j k$

Keterangan:

Yijk $=$ Nilai pengamatan faktor klon pada taraf ke-I, faktor perendaman pada taraf ke-j dan ulangan ke-k.

$\mu=$ Nilai tengah populasi

$\alpha \mathrm{i}=$ Pengaruh faktor klon pada taraf ke-i

$\beta \mathrm{j}=$ Pengaruh faktor perendaman pada taraf ke-j

$\alpha \beta \mathrm{ij}=$ Interaksi faktor klon pada taraf ke-i dan faktor perendaman pada taraf ke-j

$\varepsilon i j k=$ Pengaruh galat pada faktor klon taraf ke$i$, faktor perendaman pada taraf ke-j dan ulangan ke-k.

Data hasil pengamatan dianalisis secara statistik menggunakan analisis ragam (Annova) dan perlakuan yang berbeda nyata dilakukan uji lanjut dengan uji BNJ (Beda Nyata Jujur). 


\section{Tahap Pelaksanaan}

\section{Persiapan Sampel}

Umbi talas yang digunakan adalah umbi talas yang dipanen pada umur 9 bulan. Talas yang dipanen adalah talas yang ditanam di daerah Cijeruk dari dua klon yaitu klon B-1511 dan B-1023. Beberapa hari setelah panen, umbi talas dikupas, dipotong dan diberi perlakuan perendaman. Talas Klon B-1511 dan B1023 ditimbang, kemudian dikupas dan masing-masing kulit hasil kupasan dipisahkan. Talas diiris menggunakan alat slicer dengan ketebalan chip sebesar 2 $\mathrm{mm}$. Setelah dihasilkan chip, dari masingmasing klon dibagi ke dalam sembilan wadah untuk diberi perlakuan perendaman sesuai dengan perlakuan percobaan yaitu klon B-1511 tanpa perendaman (kontrol).

\section{Proses Penepungan}

Setelah didapatkan chip kering, kemudian diblender dan diayak bertahap menggunakan ayakan 100 mesh. Selanjutnya tepung dianalisa yang meliputi rendemen, kadar air, densitas kamba, amilosa, amilopektin, kadar pati dan kadar kalsium oksalat.

\section{Variabel Pengamatan}

Variabel yang diamati pada penelitian ini diantaranya adalah rendemen, kadar air, densitas kamba, kadar amilosa, amilopektin, kadar pati dan kalsium oksalat.

\section{Rendemen Tepung Talas}

Pengukuran rendemen tepung talas dimaksudkan untuk mengetahui tingkat efisiensi proses pengeringan dan penepungan umbi Talas Bogor. Rendemen tepung talas dapat dihitung dengan:

Rendemen $=\underline{\text { Tepung talas } 100 \text { mesh }} \times 100 \%$ Berat awal dengan kode $\mathrm{K} 1$, $\mathrm{K} 2$ dan $\mathrm{K} 3$, perlakuan perendaman dengan air yang diberi kode $\mathrm{A} 1$, A2 dan $\mathrm{A} 3$, perlakuan perendaman dengan larutan garam 5\% dengan kode G1, G2 dan G3. Dimana setiap perlakuan diulang tiga kali. Setelah didiamkan 30 menit, sampel dicuci dan dibilas sampai lendir yang berasal dari talas sedikit berkurang. Kemudian sampel ditiriskan dengan menggunakan tray. Setelah ditiriskan, sampel dikeringkan di dalam drying oven pada suhu $50-60^{\circ} \mathrm{C}$ selama 8 9 jam. Chip yang dihasilkan dari proses pengeringan, ditepungkan dengan blender, kemudian diayak dengan ayakan 100 mesh. Tepung yang digunakan untuk analisa adalah tepung lolos 100 mesh dan masing-masing diambil sebanyak 50 gram.

\section{Kadar Air}

Kadar air diukur dengan menggunakan metode oven (Whistler, 1965) dalam (Fitri, 2013). Satu gram sampel ditimbang kemudian dimasukkan ke dalam cawan alumunium yang telah diketahui beratnya, kemudian dimasukkan dalam oven selama 3 jam pada suhu $105^{\circ}$ C. Setelah itu dimasukkan dalam desikator dan ditimbang. Kadar air dihitung dengan dengan menggunakan rumus sebagai berikut.

Kadar air $(\%)=\underline{\text { Berat awal }- \text { Berat Akhir }} \times 100 \%$ Berat awal

\section{Densitas K}

Densitas kamba adalah jumlah massa persatuan volume yangdinyatakan dalam $\mathrm{g} / \mathrm{ml}$ atau $\mathrm{g} / \mathrm{cm}^{3}$. Densitas kamba ditentukan oleh berat sampel dalam wadah yang diketahui volumenya. Pembagian berat sampel dengan volume wadah merupakan nilai densitas kamba (Early, 1998) dalam (Rinaldi, 2018). 


\section{Kadar Pati}

Kadar pati diukur dengan metode iodine affinity (Kawabata et al., 1984). Sebanyak 3 gram sampel tepung ditimbang dan dimasukkan ke dalam erlenmeyer $500 \mathrm{ml}$, kemudian ditambahkan $30 \mathrm{ml}$ aquadest. Kemudian dikocok dengan menggunakan alat shacker selama 30 menit. Setelah itu diambil sebanyak $10 \mathrm{ml}$ ke dalam erlenmeyer, ditambahkan empat tetes indikator kanji ke dalam sampel lalu dititrasi dengan larutan $I_{2} 0,1 \mathrm{~N}$ hingga larutan berubah warna menjadi hitam kebiru-biruan. Kadar pati dihitung berdasarkan hasil titrasi yang menunjukkan iodine affinity dari pati:

$\operatorname{IAS}(\mathrm{mg} / \mathrm{L}=\underline{\mathrm{VD}} \times \underline{\mathrm{Vt}} \times \underline{\mathrm{NA}} \times 106 \times 1000$ VA Ms 100

Keterangan:

$\mathrm{VD}=$ Total volume terdispersi

$\mathrm{VA}=$ Volume larutan yang digunakan untuk titrasi

$\mathrm{Vt}=$ Volume titran

Ms = Bobot sampel yang digunakan

$\mathrm{NA}=$ Normalitas larutan iodin yang digunakan

\section{Kadar Amilosa}

Deret standar disusun dengan cara membuat 5 replikat standar pada konsentrasi berbeda. Sebanyak 40 gram amilum murni ditimbang dan dimasukkan ke dalam labu takar $100 \mathrm{ml}$. Kemudian ditambahkan etanol $1 \mathrm{ml}$ dan $9 \mathrm{ml} \mathrm{NaOH}$ $1 \mathrm{~N}$ dipanaskan selama 10 menit dengan suhu $60^{\circ} \mathrm{C}$. Setelah dipanaskan, ditera sampai tanda tera. Kemudian membuat deret 1,2,3,4 dan $5 \mathrm{ml}$ dan ditambahkan asam asetat 0,2, 0,4, 0,6, 0,8 dan $1 \mathrm{ml}$ kemudian masing-masing ditambahkan 2 ml larutan iod, dan ditera. Diamkan selama 20 menit, kemudian dibaca spektrofotometer.

Sebanyak $100 \mathrm{mg}$ sampel ditimbang dan dimasukkan ke dalam labu $100 \mathrm{ml}$, kemudian ditambahkan etanol $95 \% 1 \mathrm{ml}$ dan $\mathrm{NaOH} 1 \mathrm{~N} 9 \mathrm{ml}$. Sampel dipanaskan selama 10 menit di atas waterbath. Setelah dipanaskan, didinginkan kemudian ditambahkan aquadest sampai batas tera. Lima (5) ml sampel dimasukkan ke dalam labu $100 \mathrm{ml}$ kemudian ditambahkan $\mathrm{CH}_{3} \mathrm{COOH} 1 \mathrm{~N} 1 \mathrm{ml}$ dan larutan iod sebanyak $2 \mathrm{ml}$. Setelah itu ditambahkan aquadest sampai batas tera, dikocok kemudian didiamkan selama 20 menit. Setelah didiamkan, absorbansi diukur dengan Spektrofotometer UV-Vis pada panjang gelombang $620 \mathrm{~nm}$. Kadar amilosa dihitung dengan rumus:

$$
\text { Kadar amilosa }=\frac{\mathrm{C} \times \mathrm{VX} \times \mathrm{Fp}}{\mathrm{N}} \times 100
$$

$$
\begin{aligned}
& \text { Keterangan } \\
& \mathrm{C}=\text { Slope } \\
& \mathrm{VX}=\text { Volume akhir } \\
& \mathrm{Fp}=\text { Faktor pengencer } \\
& \mathrm{N}=\text { Bobot sampel }
\end{aligned}
$$

\section{Kadar Amilopektin}

Penentuan kadar amilopektin dihitung dari selisih antara kandungan pati dengan amilosa.

Kadar amilopektin $(\%)=$

kadar pati (\%) - kadar amilosa (\%)

\section{Kadar Kalsium Oksalat}

Menimbang sampel sebanyak 5 gram pada cawan porselen. Kemudian sampel diarangkan sampai asap hilang. Setelah itu dinginkan, kemudian ditanur selama 30 menit dengan suhu bertahap yaitu 200, 400 sampai suhu $600^{\circ}$ C. Setelah 30 menit, sampel dibiarkan dingin sebelum dikeluarkan dari tanur. Ke dalam sampel ditambahkan $\mathrm{HNO}_{3}$ : aquadest yaitu 1:1 sebanyak $10 \mathrm{ml}$. Kemudian dianalisa menggunakan alat AAS (Atomic Absorption Spektrophotometry.

\section{HASIL DAN PEMBAHASAN}

Hasil pengamatan terhadap variabel tepung talas yang diteliti meliputi: rendemen, Kadar air, densitas kamba, amilosa, amilopektin dan kadar pati disajikan pada Tabel 2. 
Tabel 2. Rata-rata hasil pengamatan sifat fisika-kimia tepung talas bogor (Colocasia esculenta)

\begin{tabular}{rlrccccc}
\hline \multirow{2}{*}{ Klon } & Perlakuan & Rendemen & KA & $\begin{array}{c}\text { Densitas Kamba } \\
\%\end{array}$ & Amilosa & Amilopektin & Pati \\
\hline B 1511 & Kontrol & 26,8 & 4,43 & 1,13 & $11,01 \mathrm{~b}$ & $40,07 \mathrm{~b}$ & $51,08 \mathrm{~b}$ \\
& Air & 27,6 & 4,98 & 1,15 & $8,29 \mathrm{a}$ & $33,17 \mathrm{a}$ & $41,46 \mathrm{a}$ \\
& Garam (5\%) & 25,2 & 5,58 & 1,14 & $11,67 \mathrm{~b}$ & $28,05 \mathrm{a}$ & $39,72 \mathrm{a}$ \\
B 1023 & Kontrol & 30,0 & 5,10 & 1,15 & $13,53 \mathrm{~b}$ & $25,70 \mathrm{a}$ & $39,23 \mathrm{a}$ \\
& Air & 26,0 & 5,17 & 1,12 & $12,28 \mathrm{~b}$ & $31,15 \mathrm{~b}$ & $43,43 \mathrm{~b}$ \\
& Garam (5\%) & 23,2 & 4,93 & 1,14 & $7,62 \mathrm{a}$ & $26,11 \mathrm{a}$ & $33,73 \mathrm{a}$ \\
\hline
\end{tabular}

Keterangan: angka yang diikuti huruf yang sama pada kolom yang sama menujukkan berbeda tidak nyata

\section{Rendemen Tepung Talas}

Berdasarkan analisis ragam (Annova), tidak ditemukan adanya interaksi antara klon dan perlakuan perendaman terhadap rendemen tepung talas. Demikian pula dengan pengaruh masing-masing faktor.

Tabel 2 terlihat bahwa Klon B-1023 menghasilkan rendemen tepung talas tertinggi yaitu $30,0 \%$ pada perlakuan kontrol (tanpa perendaman) dan rendemen terendah pada perlakuan perendaman dalam air garam yaitu 23,2\%. Hal ini diduga karena garam bersifat higroskopis, sehingga pada saat perendaman dalam air garam, beberapa senyawa larut air akan keluar dari sel dan jaringan umbi sebagai akibat perbedaan tekanan osmotik antara cairan di dalam sel atau jaringan umbi talas dengan lautan garam. Keluarnya senyawa-senyawa larut air ini akan mengurangi massa tepung talas. Rata-rata rendemen tepung talas bogor klon B 1511 sebesar 26,53\% dan B 1023 26,40\%. Pada proses pembuatan tepung, khususnya pada proses pengeringan, terjadi kehilangan bobot yang paling besar. Proses pengeringan menyebabkan hilangnya kandungan air dari umbi talas. Ketika proses penepungan menggunakan blender, terjadi kehilangan bobot akibat tepung yang melayang dan menempel pada blender. Pada proses selanjutnya yaitu proses pengayakan masih terdapat kehilangan bobot. Hal ini diakibatkan oleh tepung talas yang tidak cukup halus untuk lolos ayakan 100 mesh sehingga tertinggal di atas ayakan sehingga dihasilkan rendemen yang rendah.

\section{Kadar Air}

Berdasarkan analisis ragam (Annova), interaksi antara klon dan perendaman berbeda tidak nyata terhadap kadar air tepung talas. Demikian pula dengan masing-masing faktor. Berdasarkan (Tabel 2), kadar air tepung talas tertinggi terdapat pada klon B-1511 dengan perlakuan perendaman dalam larutan garam 5\% yaitu sebesar 5,58\%. Kadar air tepung talas terendah berasal dari klon B1511 yaitu sebesar $4,43 \%$ dengan perlakuan tanpa perendaman. Perlakuan perendaman dalam larutan garam 5\% memiliki kadar air yang paling tinggi dibandingkan dengan kadar air tepung dengan perlakuan yang lain disebabkan oleh garam yang mempunyai sifat higroskopis, artinya larutan garam 5\% mengikat lebih banyak air sehingga tepung yang diberi perlakuan tersebut merupakan tepung dengan kadar air tertinggi.

Menurut Kafah (2012), air merupakan komponen yang penting dalam bahan makanan karena air dapat mempengaruhi penampakan, tekstur, dan cita rasa serta berpengaruh terhadap tingkat penerimaan konsumen dan daya simpan bahan tersebut. Kadar air yang rendah pada tepung talas dapat memperpanjang umur 
simpan tepung dibandingkan dengan umur simpan umbi segarnya. Disamping itu, kadar air rendah juga dapat menekan dan menghambat pertumbuhan mikroorganisme perusak bahan makanan. Pengeringan dapat menurunkan kadar air bahan, sehingga aktivitas mikroorganisme dapat dihambat. Disamping itu kandungan karbohidrat, lemak, protein dan mineral dalam bahan pangan juga akan yang lebih tinggi (Muchtadi dan Sugiyono, 1989). Dengan demikian perendaman dalam larutan garam dapat memperpanjang umur simpan tepung talas, karena perlakuan ini menghasilkan tepung dengan kadar air terendah.

\section{Densitas Kamba}

Densitas kamba adalah sifat fisik bahan pangan dari tepung-tepungan yang merupakan perbandingan antara berat bahan terhadap volume bahan pangan. Suatu bahan dikatakan kamba apabila nilai densitas kambanya kecil, artinya berat yang ringan menempati ruang atau volume yang besar.

Berdasarkan annova, interaksi antara klon dan perendaman berbeda tidak nyata terhadap hasil pengukuran densitas kamba tepung talas. Rata-rata densitas kamba tepung talas disajikan pada Tabel 2.). Densitas kamba tertinggi terlihat pada Klon B-1511 pada perlakuan perendaman dalam air dan pada klon B-1023 pada perlakuan tanpa perendaman yaitu sebesar $1,15 \%$. Sedangkan densitas kamba terendah terdapat pada klon B-1023 pada perlakuan perendaman dalam air sebesar $1,12 \%$.

Densitas kamba dapat digunakan untuk memprediksi efektifitas dan efisiensi volume ruang yang dibutuhkan untuk suatu bahan pangan dengan berat tertentu. Semakin besar nilai densitas kamba maka semakin efektif dan efisien dalam penyimpanan karena dengan jumlah volume (ruang) penyimpanan sama, maka jumlah bobot bahan yang dapat ditampung akan lebih banyak. Nilai densitas kamba dapat juga digunakan untuk merencanakan gudang penyimpanan, merancang volume alat pengolahan maupun sarana transportasinya (Kafah, 2012).

Kandungan air yang tinggi pada tepung talas menyebabkan berat tepung talas lebih besar pada wadah dengan volume yang sama dan menyebabkan densitas kamba menjadi lebih besar. Kadar air tinggi menyebabkan partikel tepung menjadi lebih berat dan volume pada rongga partikel menjadi kecil. Hal ini menyebabkan nilai densitas kamba yang dimiliki semakin besar (Prabowo, 2010).

\section{Kadar Amilos}

Amilosa merupakan polimer dari glukosa. Bentuk cincin glukosa dengan enam unit atom karbon mengakibatkan amilosa dapat membentuk kompleks dengan berbagai molekul kecil yang $\mathrm{t}$ masuk ke dalam lingkarannya. Warna biru tua pada penambahan iod merupakan contoh pembentukan kompleks. Amilosa merupakan komponen larut dalam air pada suhu $70-80^{\circ} \mathrm{C}$ (Boediono, 2012).

Berdasarkan anilisis ragam (Tabel 2.), interaksi antara klon dan perlakuan perendaman berbeda nyata terhadap kadar amilosa tepung talas. Berdasarkan uji lanjut dengan BNJ 5\%, didapatkan hasil bahwa perlakuan perendaman dalam air pada tepung talas klon B-1511 mengandung amilosa paling rendah berbeda nyata dengan perendaman dalam larutan garam dan kontrol. Pada klon B1023, perendaman dalam larutan garam 5\% mengandung amilosa paling rendah. Namun secara umum amilosa tertinggi terdapat pada perlakuan kontrol (tidak direndam) baik pada klon B-1511 dan B1023. Hal ini diduga karena amilosa larut dalam air, sehingga perlakuan perendaman dalam air maupun dalam larutan garam 5\% akan menurunkan kadar amilosa. 


\section{Kadar Amilopektin}

Amilopektin adalah polisakarida tak larut dalam air yang merupakan polimer dari glukosa dengan rantai cabang. Amilopektin dapat membentuk kristal yang kereaktifannya lebih rendah jika dibandingkan dengan amilosa. Rantai percabangan merupakan penyebab yang menghalangi pembentukan kristal (Boediono, 2012).

Berdasarkan analisis ragam (Tabel.2). interaksi antara klon dan perlakuan perendaman berbeda nyata terhadap kadar amilopekti.

Hasil uji lanjut dengan BNJ 5\% diketahui pada tepung talas klon B-1511, amilopektin pada perlakuan kontrol tertinggi $(40,07 \%)$ dan berbeda nyata dengan perlakuan lainnya. Sedangkan pada klon B-1023, kadar amilopektin tertinggi $(31,15 \%)$ terdapat pada perlakuan perendaman dalam air, berbeda nyata dengan perlakuan lainnya. Dua karakter yang berbeda antara kedua klon, dimana pada Klon B-1511, kadar amilopektin menurun dengan perlakuan perendaman. Sedangkan pada klon B 1023, perlakuan perendaman menaikkan kadar amilopektin. Hal ini diduga karena rata-rata kadar air pada B-1511 lebih rendah dibandingkan dengan rata-rata kadar air pada B-1023. Menurut Wahyudi (2003) pati dengan kadar amilopektin tinggi sesuai untuk digunakan sebagai bahan baku roti dan kue, karena sifat amilopektin yang dapat mempengaruhi sifat mengembang pada pati (swelling properties).

\section{Kadar Pati}

Pati dalam umbi talas mudah dicerna dengan bantuan enzim amilase dalam air liur menjadi gula sederhana. Hal ini menjadikan tepung talas sangat cocok menjadi bahan makanan terutama untuk balita yang menderita alergi makanan dan orang dewasa yang mengalami gangguan pencernaan (Ariyanti, 2014). Menurut Rohmah (2013) sifat fungsional pati pada tepung juga dipengaruhi oleh varietas, kondisi alam dan tempat tanaman berasal.

Berdasarkan tabel annova (Tabel 2.), interaksi kedua faktor berbeda nyata terhadap hasil uji kadar pati sehingga dilakukan uji lanjut BNJ untuk mengetahui apakah perlakuan berbeda secara statistik atau tidak. Hasil uji lanjut dengan BNJ 5\% menunjukkan bahwa perlakuan tanpa peredaman (kontrol) pada klon B-1511 mengandung pati tertinggi $(51,08 \%)$ tertinggi dan berbeda nyata terhadap perlakuan lainnya. Sedangkan pada klon B-1023, kadar pati tertinggi terdapat pada perlakuan perendaman dengan air $(43,43 \%)$ tertinggi dan berbeda dengan lainnya. Karakter yang berbeda pada kedua klon yang diuji ini diduga karena rata-rata KA pada klon B-1023 lebih tinggi dibandingkan dengan KA klon B-1511.

Menurut Wahyudi (2003), pati merupakan komponen penting yang perlu diperhatikan keberadaannya dalam tepung. Pati disusun dari dua macam polisakarida yaitu: amilosa dan amilopektin dalam persentase yang berbeda-beda. Amilosa merupakan polimer glukosa dengan rantai lurus memberikan sifat keras, sedangkan amilopektin dengan rantai bercabang menyebabkan sifat lengket.

\section{Kadar Kalsium Oksalat}

Senyawa oksalat terdapat di dalam sel tanaman, terutama dalam bentuk asam oksalat atau garam kalsium oksalat. Asam oksalat larut dalam air, sedangkan kalsium oksalat tidak larut dalam air, namun dapat larut dalam asam kuat (Sefa dan Sackey, 2004). Kandungan kalcium oksalat pada tepung talas yang diteliti dapat dilihat pada (Tabel 3). 
Tabel 3. Rata-rata kadar Kalsium Oksalat

\begin{tabular}{cccc}
\hline Klon & $\begin{array}{c}\text { Kontrol } \\
(\mathrm{mg} / \mathrm{kg})\end{array}$ & $\begin{array}{c}\text { Air } \\
(\mathrm{mg} / \mathrm{kg})\end{array}$ & $\begin{array}{c}\text { Garam } \\
(\mathrm{mg} / \mathrm{kg})\end{array}$ \\
\hline B-1511 & 1.300 & 489 & 387 \\
B-1023 & 800 & 466 & 448 \\
\hline
\end{tabular}

Rata-rata kadar kalsium oksalat tertinggi dimiliki oleh tepung talas klon B1511 sebesar $1.300 \mathrm{mg} / \mathrm{kg}$ yang merupakan tepung talas dengan perlakuan tanpa perendaman (kontrol). Sedangkan kadar kalsium oksalat terendah dimiliki oleh tepung talas dengan perlakuan perendaman dalam larutan garam 5\% pada klon yang sama yaitu sebesar $387 \mathrm{mg} / \mathrm{kg}$. Berdasarkan hasil tersebut, kadar kalsium oksalat pada tepung talas klon B-1511 dan klon B-1023 berturut-turut dapat menurun sesuai dengan perlakuan yang diberikan. Berdasarkan perlakuan yang diberikan, perlakuan perendaman dalam larutan garam 5\% efektif menurunkan kalsium oksalat yang terdapat pada umbi talas. Hal ini disebabkan karena pada saat perendaman terjadi proses osmosis, di mana pada proses osmosis adanya tekanan air terhadap dinding sel umbi sehingga kristal kalsium oksalat yang berbentuk jarum akan keluar selama proses perendaman. Perendaman dalam larutan garam dapat menurunkan kadar kalsium oksalat karena $\mathrm{NaCl}$ di dalam air mengalami ionisasi menjadi $\mathrm{Na}^{+}$dan $\mathrm{Cl}^{-}$. Ion natrium $\left(\mathrm{Na}^{+}\right)$yang terbentuk selanjutnya berikatan dengan oksalat di dalam kalsium oksalat membentuk senyawa natrium oksalat sedangkan ion $\mathrm{Cl}^{-}$berikatan dengan kalsium membentuk endapan $\mathrm{CaCl}_{2}$ (kalsium diklorida) yang dapat larut di dalam air. Kalsium oksalat dapat larut di dalam air jika strukturnya diubah menjadi asam oksalat. Menurut Simpson et al. (2009), kondisi asam menyebabkan ion oksalat $\left(\mathrm{C}_{2} \mathrm{O}_{4}{ }^{2-}\right)$ akan terdeprotonasi sehingga dapat mengurangi kemampuan berikatan dengan kation $\mathrm{Ca}^{2+}$ untuk menjadi kalsium oksalat yang tidak terlarut. Hal ini menyebabkan semakin meningkatnya oksalat terlarut dalam air perendaman yang selanjutnya akan dibuang. Disamping itu, potensi berikatan antara ion kalsium dengan ion oksalat akan berkurang pada $\mathrm{pH}$ rendah sehingga asam oksalat yang larut akan semakin banyak terbentuk.

\section{KESIMPULAN DAN SARAN}

Hal-hal yang dapat disimpulkan dari penelitian ini adalah terdapat interaksi yang nyata antara klon dan perlakuan perendaman terhadap kadar amilosa, kadar amilopektin dan kadar pati. Namun tidak ada interaksi antara klon dan perlakuan perendaman pada rendemen, kadar air dan densitas kamba.

Perlakuan perendaman dalam larutan garam 5\% selama 30 menit dapat menurunkan kadar kalsium oksalat pada tepung talas baik klon B-1511 maupun B 1023. Rata-rata rendemen tepung pada klon B-1511 26,53\% sedangkan untuk klon B-1023 26,40\%.

Disarankan perlu kajian lebih lanjut pemanfaatan tepung talas untuk keperluan bahan baku industri rerotian. menghasilkan karakteristik tepung talas yang lebih baik sebagai bahan pangan pengganti tepung-tepung yang lainnya dan disarankan menggunakan larutan garam untuk tujuan menurunkan kalsium oksalat pada umbi talas karena larutan garam efektif menurunkan kalsium oksalat.

\section{DAFTAR PUSTAKA}

Rinaldi, Ahmad. (2018). Penentuan Densitas Kamba Susu Bubuk Sebelum dan Sesudah Pencampuran Kering. Bogor: Jurnal IPB Repository. 
Amalia Dwi Lestari dan Shinta Maharani. (2017). Pengaruh Substitusi Tepung Talas Belitung Terhadap Karakteristik Fisika, Kimia dan Tingkat Kesukaan Konsumen pada Roti Tawar. Jurnal UPI Edufortech.

Ariyanti, D., C. S. Budiyati dan A. C. Kumoro. (2014). Modifikasi Tepung Umbi Talas Bogor (Colocasia esculenta L. Schott) dengan Teknik Oksidasi sebagai Bahan Pangan Pengganti Tepung Terigu. Reaktor. Semarang, 15(1), 1-9.

Boediono, M.P.A.D.R. 2012. Pemisahan dan pencirian amilosa dan amilopektin dari pati jagung dan pati kentang pada berbagai suhu. Skripsi.Bogor: Fakultas Matematika dan Ilmu Pengetahuan Alam Institut Pertanian Bogor.

Farhandi Saputra, Amna Hartiati, dkk. (2016). Karakteristik Mutu Pati Ubi Talas (Colocasia esculenta) pada Perbandingan Air dengan Hancuran Ubi Talas dan Konsentrasi Natrium Metabisulfit. Jurnal Rekayasa dan Manajemen Agroindustri, 4 (1), 62-71.

Fitri Diana Wulansari. (2013). Metode Sederhana Penentuan Jumlah Unit Pengulangan Glukosa dalam Amilosa Sebagai Media Pembelajaran Materi Karbohidrat. Jurnal Pengajaran MIPA, 18(2), 185-190.

Widhyastini, I.G.A.M. dan Hutagaol, R. P. (2014). Pemanfaatan Talas Bogor (Colocasia esculenta L. Schott) Sebagai Larvasida Nyamuk. Jurnal Sains Natural Universitas Nusa Bangsa, 4(2), 92-97.
Jannah, A. F. Nurilmala, A. Masnang dan RF. Ramdhiana. (2019). Teknologi Pacapanen Talas Bogor (Colocasia esculenta) untuk penguatan Agroindustri Berbahan Baku Sumber Daya Lokal. Prosiding Seminar dan Lokakarya Nasional FKPTPI 2019. Universitas Pajajaran. Bandung

Kafah, F.F.S. (2012). Karakteristik Tepung Talas (Colocasia esculenta (L) Schott) dan Pemanfaatannya dalam Pembuatan Cake. Skripsi. Fakultas Teknologi Pertanian IPB. Bogor.

Kawabata, A., Sawayama, S., Nagashima, N., Del Rosario, R.R., dan Nakamura, M. (1984). Some Physico-chemical Properties of Starches from Cassava, Arrow Root and Sago. J Jpn Soc Starch Sci. 31: 224-232.

Muchtadi, T.R., dan Sugiyono. (1989). Petunjuk Laboratorium Ilmu Pengetahuan Bahan Pangan. Pusat Antar Universitas Pangan dan Gizi. Institut Pertanian Bogor. Bogor.

Prabowo, Bimo. (2010). Kajian Sifat Fisikokimia Tepung Millet Kuning dan Tepung Millet Merah. Skripsi. Prodi. Teknologi Hasil Pertanian. UNS. Surakarta.

Rohmah, M. (2013). Kajian Kandungan Pati, Amilosa dan Amilopektin Tepung dan Pati pada Beberapa Kultivar Pisang (Musa spp). Prosiding Seminar Nasional Kimia. ISBN:978-602-19421-0-9.

Sefa, S., dan Sackey E.K.A. (2004). Chemical Composition and the Effect of Processing on Oxalate 
Content of Cocoyam Xanthosoma sagittifolium and Colocasia esculenta cormels. Food Chemistry. 85(4): 479-487.

Simpson, T.S., Savage, G.P., Sherlock, R. and Vanhanen, L. (2009). Oxalate content of silver beet leaves at different stages of maturation and the effect of cooking with different milk sources. Journal of Agricultural and Food Science, 57(22), 10804-10808.

Wahyudi. (2003). Memproduksi Roti. Direktorat Pendidikan Menengah Kejuruan, Direktorat Jenderal Pendidikan Dasar dan Menengah Departemen Pendidikan Nasional. Jakarta: Departemen Pendidikan Nasional RI. 